\title{
Membangun Kesadaran Kebersihan Diri dan Lingkungan Pada Siswa TK \& SD Tunas Benih Kasih Surabaya
}

\author{
Prida Ariani Ambar Astuti ${ }^{1}$, Prayogo Maulana ${ }^{2}$, Agathon Agnar Ramadhan $^{3}$, Danny Alfaridzi ${ }^{4}$, \\ Grace Putri Amelia ${ }^{5}$, Rahman Hakim Averus ${ }^{6}$ \\ Program Studi Ilmu Komunikasi \\ Sekolah Tinggi Ilmu Komunikasi - Almamater Wartawan Surabaya (Stikosa-AWS) \\ Jl. Nginden Intan Timur 1/18 Surabaya 60118 \\ Email: pridaariani@stikosa-aws.ac.id
}

\begin{abstract}
The government continues to strive to educate the public to care about environmental cleanliness. Even so, cases of disease caused by a lack of awareness of environmental hygiene have increased every year. For this reason, awareness of environmental cleanliness needs to be instilled from an early age so that disease cases caused by hygiene problems can be overcome. Preliminary research has identified that there are still many kindergarten and elementary school students in Tunas Benih Kasih Surabaya who are accustomed to littering. Most students are ignorant of the cleanliness of the classroom and school environment by throwing food wrappers and paper carelessly. The findings of this preliminary research then become the basis for the use of educational posters and videos as a tool to build awareness of personal and environmental hygiene in Tunas Benih Kasih Surabaya kindergarten and elementary school students. Educational activities to improve health have been shown to be able to change people's behavior. Determining the theme, formulating messages, choosing words and photos to be used, and combining other elements to make interesting posters and videos, are important stages in making educational videos and posters. In the future, this community service activity can be continued by conducting research using experimental methods to determine the impact of these educational videos and posters on the awareness of kindergarten and elementary school students of Tunas Benih Kasih Surabaya in maintaining personal hygiene and the environment.
\end{abstract}

Keywords: Education, Hygiene, Videos, Posters, Early Childhood

\begin{abstract}
Abstrak
Upaya untuk mengedukasi masyarakat agar peduli terhadap kebersihan lingkungan terus digalakkan pemerintah. Meskipun demikian, kasus-kasus penyakit yang disebabkan karena kurangnya kesadaran akan kebersihan lingkungan setiap tahunnya selalu mengalami peningkatan. Untuk itu, kesadaran akan pentingnya kebersihan lingkungan perlu ditanamkan sejak usia dini sehingga ke depan kasus penyakit yang diakibatkan masalah kebersihan dapat diatasi. Riset pendahuluan yang dilakukan berhasil mengidentifikasi bahwa masih banyak siswa TK dan SD Tunas Benih Kasih Surabaya yang terbiasa membung sampah sembarangan. Kebanyakan siswa bersikap abai terhadap kebersihan lingkungan kelas dan sekolah dengan membuang bungkus makanan maupun kertas secara sembarangan. Temuan penelitian awal ini selanjutnya menjadi landasan penggunaan metode untuk membangun kesadaran kebersihan diri dan lingkungan pada siswa TK dan SD Tunas Benih Kasih Surabaya yaitu dengan menggunakan media poster dan video edukasi. Kegiatan untuk melakukan edukasi guna meningkatkan kesehatan telah terbukti mampu mengubah perilaku masyarakat. Penentuan tema, merumuskan pesan yang ingin disampaikan, pemilihan kata dan gambar yang akan digunakan dan memperhatikan perpaduan elemen-elemen lain yang dibutuhkan dalam pembuatan poster dan video, merupakan tahapan yang perlu diperhatikan dalam pembuatan video dan poster edukasi. Ke depan, kegiatan PkM ini dapat dilanjutkan dengan melakukan penelitian menggunakan metode eksperimental untuk mengetahui dampak tayangan video dan poster edukasi tersebut terhadap kesadaran siswa TK dan SD Tunas Benih Kasih Surabaya dalam menjaga kebersihan diri dan lingkungan.
\end{abstract}


Kata Kunci: Edukasi, Kebersihan, Video, Poster, Anak Usia Dini

\section{PENDAHULUAN}

Kebersihan lingkungan berkorelasi erat dengan kesehatan. Lebih-lebih di masa Pandemi Covid-19 seperti saat ini yang menuntut kita untuk memiliki imunitas yang mumpuni agar tidak terkena virus yang telah memakan banyak korban di seluruh dunia. Berdasarkan data dari covid.19.go.id, sebanyak 1,210,703 orang telah terkonfirmasi positif terdampak Covid-19, 1,016,036 orang telah dinyatakan sembuh, dan 32,936 orang dinyatakan meninggal dunia (2021). Di Indonesia, pandemi Covid-19 telah ditangani pemerintah secara serius. Meskipun demikian, pemerintah tidak mungkin sendiri menghadapi pandemi ini tanpa peran serta masyarakat. Pemanfaatan metode pentaheliks berbasis komunitas menjadi ujung tombak dalam perang melawan Covid-19 (Jawa Pos, 2020).

Kebersihan lingkungan juga sangat berperan dalam upaya pemberantasan Covid-19 karena tanpa kebersihan dan kepedulian terhadap lingkungan, pandemi ini tidak akan pernah berakhir. Terkadang pada saat kita sehat, kita lupa betapa bernilainya kesehatan dan ketika kita sakit, baru kita menyadari bahwa kesehatan sungguh sangat berharga. Rajin berolah raga, mengkonsumsi makanan bergizi, dan kebersihan lingkungan menjadi 3 kunci utama dalam membentuk tubuh yang sehat. Sayangnya lingkungan yang sehat sering kita abaikan karena beragam kesibukan sehari-hari dan akibatnya, menimbulkan berbagai macam penyakit.

Upaya untuk mengedukasi masyarakat agar peduli terhadap kebersihan lingkungan terus digalakkan pemerintah. Meskipun demikian, kasus-kasus penyakit yang disebabkan karena kurangnya kesadaran akan kebersihan lingkungan setiap tahunnya selalu mengalami peningkatan. Untuk itu, kesadaran akan pentingnya kebersihan lingkungan perlu ditanamkan bahkan sejak usia dini sehingga ke depan kasus penyakit yang diakibatkan masalah kebersihan dapat diatasi. Pentingnya untuk menumbuhkan kesadaran akan kebersihan lingkungan sejak dini ini mendorong Stikosa-AWS melakukan program pengabdian masyarakat di TK dan SD Tunas Benih Kasih Surabaya karena anak perlu berperan dalam menjaga kebersihan lingkungannya. Selain itu, pentingnya menjaga kebersihan lingkungan perlu diajarkan sedini mungkin pada anak. Jika lingkungan di sekitar anak sehat, maka hal ini tentu baik demi masa depannya. Dengan hidup sehat, anak dapat tumbuh dan berkembang menjadi sosok yang bahagia dan terjamin masa depannya.

Kegiatan Pengabdian kepada Masyarakat (PkM) Stikosa-AWS ini diawali dengan melakukan penelitian pendahuluan (preliminary research) menggunakan metode observasi pada kegiatan siswa setiap harinya. Riset pendahuluan ini berhasil mengidentifikasi bahwa masih banyak siswa yang terbiasa membung sampah sembarangan. Kebanyakan siswa bersikap abai terhadap kebersihan lingkungan kelas dan sekolah dengan membuang bungkus makanan maupun kertas secara sembarangan. Selain itu, penelitian awal juga menemukan bahwa siswa baru melakukan bersih-bersih kelas ketika diperintah oleh guru dan bukan datang dari kesadaran mereka sendiri. Hasil wawancara dengan beberapa guru juga menemukan bahwa masih banyak siswa TK dan SD Tunas Benih Kasih Surabaya yang malas untuk menjaga kebersihan badan mereka sendiri dengan mandi secara rutin atau memotong kuku tangan dan kaki mereka ketika kotor atau panjang. Identifikasi permasalahan inilah yang mendorong kegiatan PkM ini dilakukan sebagai upaya untuk menumbuhkan kesadaran diri siswa terhadap kebersihan diri dan lingkungan di sekitar mereka, terutama lingkungan sekolah. 


\section{METODE PELAKSANAAN}

Kegiatan untuk melakukan edukasi guna meningkatkan kesehatan telah terbukti mampu mengubah perilaku masyarakat. Edukasi menjadi kontribuasi yang sangat penting karena dapat digunakan untuk mengatasi ancaman berbagai penyakit yang dapat membawa kematian (Rahmatina \& Erawati, 2020). Salah satu media pendidikan yang sering digunakan untuk mengedukasi masyarakat adalah poster. Bentuk poster yang sederhana, menyajikan satu ide dan untuk mncapai satu tujuan pokok, berwarna, memiliki slogan khusus, serta tulisan yang jelas dan bervariasi dapat mempermudah dan mempercepat audiens menangkat pesan yang disajikan (Harsismanto, Oktavidiati \& Astuti, 2019). Selain poster, media edukasi yang juga sering digunakan untuk mengedukasi masyarakat adalah video. Media ini merupakan penggabungan antara dua jenis media yaitu media audio dan visual yang dapat merangsang pikiran, perasaan, perhatian, kreativitas dan inovasi serta mampu memberikan pengalaman langsung kepada penonton. Proses pembelajaran dengan melibatkan lebih dari satu indera akan lebih mudah diterima dan diingat oleh penonton (Bili, Telly, \& Tanaem, 2019).

Berdasarkan temuan dalam penelitian awal, maka diputuskan bahwa metode yang digunakan untuk membangun kesadaran kebersihan diri dan lingkungan pada siswa TK dan SD Tunas Benih Kasih Surabaya adalah dengan menggunakan media poster dan video edukasi. Konten poster yang akan digunakan berbentuk infografis untuk memudahkan siswa TK dan SD memahami pesan yang disampaikan dan dapat mempraktikkannya. Infografis adalah mendesain informasi yang kompleks ke dalam visualisasi data agar dapat dipahami dengan mudah dan cepat (Lankow, Crooks \& Richie, 2012). Infografis merupakan sebuah bentuk visualisasi data (Walter \& Gioglio, 2014). Terdapat 3 jenis infografis yaitu 1) Infografis statis yang berbentuk gambar tidak bergerak, 2) infografis animasi yaitu infografis yang berbentuk video animasi, baik yang dibuat dalam bentuk 2 dimensi maupun 3 dimensi, dan 3) infografis interaktif yaitu infografis yang biasanya ditampilkan dalam website sehingga pengguna dapat berinteraksi dengan informasi yang ditampilkan melalui user interface (Kanflic, 2015). Dari 3 jenis infografis ini, diputuskan untuk menggunakan bentuk infografis yang pertama yaitu infografis statis dengan menggunakan gambar tidak bergerak. Sementara pesan yang disampaikan melalui poster dan video edukasi tersebut, selain bertujuan untuk mengedukasi dan membangun kesadaran dalam menjaga kebersihan lingkungan, juga digunakan untuk mengedukasi siswa tentang $3 \mathrm{M}$ yaitu 1) memakai masker kemana pun pergi, 2) mencuci tangan dengan sabun dan air mengalir minimal 20 detik, dan 3) menjaga jarak dan menjauhi kerumunan sebagai upaya untuk memberantas dan memerangi penyebaran Covid-19.

\section{HASIL DAN PEMBAHASAN}

\subsection{Profil TK dan SD Tunas Benih Kasih Surabaya}

TK \& SD Tunas Benih Kasih Surabaya yang beralamat di Jl. Joyoboyo Gang Kelinci. Sawunggaling, Kecamatan Wonokromo, Kota Surabaya 60242 siswanya kebanyakan adalah anak jalanan yang tinggal di pinggiran terminal Joyoboyo Surabaya. Selain belajar, mayoritas siswa di sekolah ini juga bekerja sebagai pengamen di sekitaran terminal. Sementara para siswa ini kebanyakan memiliki orang tua yang bekerja sebagai pengamen, pemulung, dan sebagian menjadi tukang sampah. Meski termasuk dalam golongan keluarga tidak mampu, masyarakat serta anak-anak yang tinggal di pinggiran terminal Joyoboyo sangat antusias dan bersemangat untuk bisa mengenyam pendidikan dan mengasah serta menambah pengetahuan mereka. 
Berdasarkan data demografi siswa TK dan SD Tunas Benih Kasih tersebut yang berasal dari keluarga tidak mampu dengan latar pendidikan rendah, maka tidaklah mengherankan jika mereka masih memiliki kebiasaan untuk membuang sampah sembarangan. Meskipun setiap paginya sebelum guru mulai mengajar di kelas, seluruh kelas dan lingkungan sekolah selalu dibersihkan, namun setelah jam istirahat, ruang kelas dan lingkungan sekitar sekolah menjadi kotor dengan berbagai sampah seperti bungkus makanan atau berbagai robekan kertas. Hasil observasi yang dilakukan oleh tim PkM juga menemukan bahwa kebanyakan siswa bersikap tidak acuh terhadap kebersihan ruang kelas dan lingkungan sekolah mereka.

Temuan pengamatan ini semakin diperkuat dengan hasil wawancara daring dengan ibu Debora Lelly Surdaryati, S.Pd. selaku Kepala Sekolah di TK dan SD tersebut yang menyatakan bahwa murid masih menunggu perintah guru untuk membersihkan ruang kelas. "Terkadang murid masih menunggu perintah guru untuk membersihkan ruang kelas. Murid kami juga ada yang malas untuk membersihkan kelas, seperti belum sadar akan kebersihan gitu loh, Mas. Terus anak-anak itu mesti kurang memperhatikan kebersihan diri seperti memotong kuku dan kadang ada yang belum mandi saat berangkat sekolah". Selain itu, ibu Debora juga menambahkan bahwa kesadaran diri murid terhadap kebersihan lingkungan sangat tergantung pada penjelasan guru. Guru disamping harus memiliki kemampuan untuk menjelaskan juga dituntut untuk dapat memberikan contoh-contoh riil dan menggunakan bentuk komunikasi lainnya yang disesuaikan dengan kemampuan dan cara berpikir siswa agar pesan yang disampaikan dapat dipahami. Jika siswa tidak memahami tujuan dan pentingnya untuk menjaga kebersihan lingkungan yang dijelaskan oleh guru maka mereka akan bersikap tidak acuh dan lalai. Dari hasil pengamatan dan wawancara dengan Kepala Sekolah TK dan SD Tunas Benih Kasih, maka dapat disimpulkan bahwa kesadaran akan kebersihan diri dan lingkungan pada siswa-siswi TK \& SD Tunas Benih Kasih perlu dibangun dan ditingkatkan.

\subsection{Proses Pembuatan Poster dan Video Edukasi "Pentingnya Kesadaran Akan Kebersihan Diri dan Lingkungan"}

Terdapat 3 tahapan pembuatan karya audio visual yang mencakup tahap praproduksi, produksi dan pascaproduksi (Zettl, 2003). Tahap praproduksi merupakan proses yang dilakukan sebelum kegiatan produksi yang mencakup:

1. Menentukan tema cerita.

2. Pembuatan sinopsis atau ringkasan cerita mulai dari awal hingga akhir cerita.

3. Pembuatan skenario atau urutan cerita yang mencakup dialog, keterangan detail adegan, waktu, lokasi, wardrobe, dan cast yang terlibat.

4. Pembuatan script atau perintah pengambilan gambar kepada kameraman termasuk pengambilan detail-detail yang diperlukan dalam penyampaian pesan.

5. Pembuatan storyboard atau scene yaitu visualisasi ide cerita yang telah ditetapkan dalam skenario.

6. Menyusun dan menetapkan:

a. Panduan untuk mengeksekusi adegan berdasarkan waktu yang telah disepakati atau sering disebut breackdown shooting.

b. Melakukan pemilihan hasil shooting untuk nantinya diedit oleh editor.

c. Menyusun gambar sesuai dengan skenario yang telah ditetapkan (offline edit on script:). 
7. Menetapkan anggaran yang dibutuhkan selama proses praproduksi hingga pascaproduksi.

Tahap praproduksi pembuatan video edukasi diawali dengan menentukan tema yang atau ide cerita yang akan menjadi inti pesan untuk membangun kesadaran akan pentingnya kebersihan lingkungan. Tema atau ide cerita ini diputuskan akan dibuat bersama antara Tim PkM dengan pihak TK \& SD Tunas Benih Kasih Surabaya. Setelah dilakukan diskusi secara daring, maka disepakati bahwa tema yang akan diangkat adalah tentang kesadaran untuk tidak membuang sampah sembarangan sekaligus edukasi protokol kesehatan untuk penanggulangan penyebaran Covid-19 dengan meminta siswa menggunakan masker seperti dapat dilihat pada Gambar 1 di bawah ini.

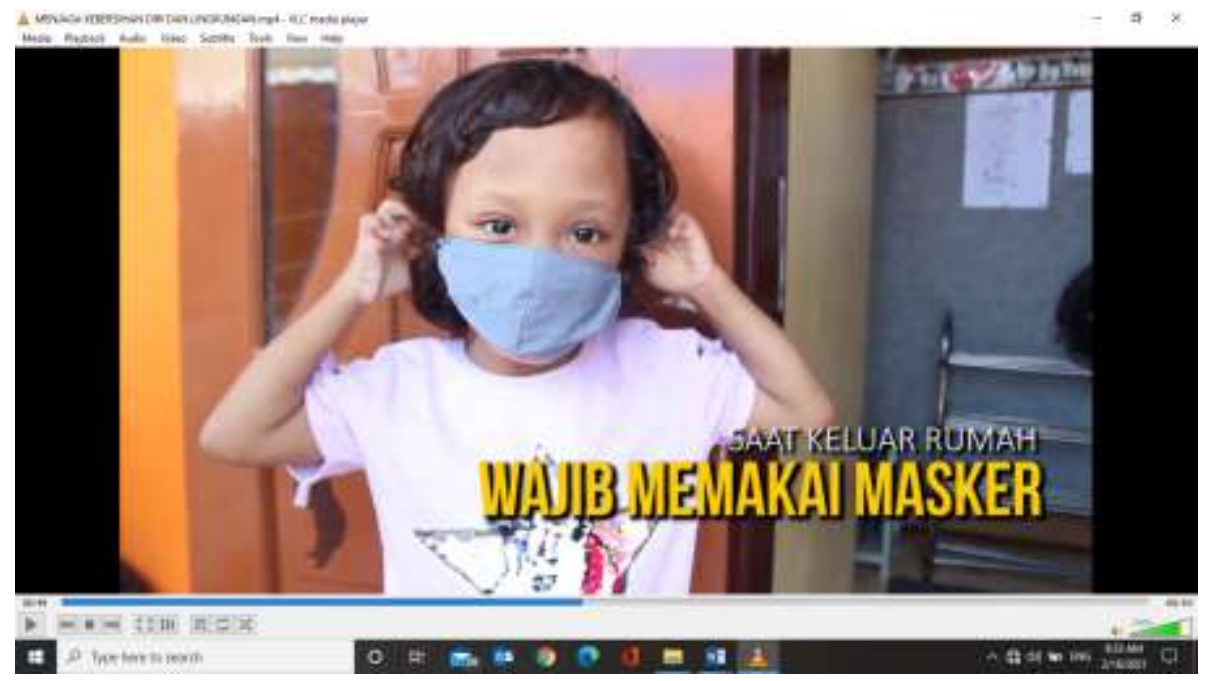

Gambar 1. Edukasi Protokol Kesehatan dengan Pesan

"Wajib Memakai Masker Saat Keluar Rumah"

Setelah tema ditetapkan, video edukasi kemudian dilanjutkan dengan pembuatan sinopsis dan skenario. Setelah melakukan diskusi panjang antar anggota tim maka diputuskan bahwa video edukasi tersebut akan dibuat seringkas dan semudah mungkin sehingga mudah untuk dipahami anak-anak TK dan SD kisaran usia 4-12 tahun. Lokasi pengambilan gambar diputuskan akan menggunakan setting di rumah serta menggunakan aktor anak-anak usia 5-7 tahun untuk membangun faktor kesamaan fisik dan psikis dengan target sasaran video. Selanjutnya, setelah menentukan adegan, waktu, lokasi, dan aktor pemeran dalam video tersebut, proses praproduksi dilanjutkan dengan membuat storyboard dan menetapkan anggaran yang dibutuhkan selama proses pembuatan video edukasi tersebut. Tetapi karena tujuan pembuatan video edukasi adalah untuk menumbuhkan dan membangun kesadaran akan kebersihan diri dan lingkungan merupakan bentuk kegiatan PkM, oleh karena itu, anggaran yang dibutuhkan ditetapkan agar zero budget. Jika ada pengeluaran dalam proses produksi video edukasi tersebut, akan ditutup dengan swadaya dari anggota tim.

Tahap kedua adalah tahap produksi yaitu tahap pelaksanaan kegiatan shooting berdasarkan ketentuan yang telah ditetapkan dalam tahap praproduksi. Shooting dalam tahap produksi ini dapat dilakukan di dalam ruangan (indoor), di luar ruangan (outdoor) atau penggabungan keduanya. Pada tahap produksi ini, selain mereka yang terlibat langsung dalam 
proses shooting atau sering disebut dengan technical production personnel, terdapat 2 posisi non-technical production personnel yaitu:

a. Producer atau sutradara yaitu seseorang yang bertanggung jawab terhadap pencapaian tujuan produksi program audio visual tersebut.

b. Executive Producer yaitu orang yang bertanggung jawab terhadap kelancaran produksi program dengan mengatur keuangan atau mengatur manajemen produksi untuk menjamin kelancaran proses produksi.

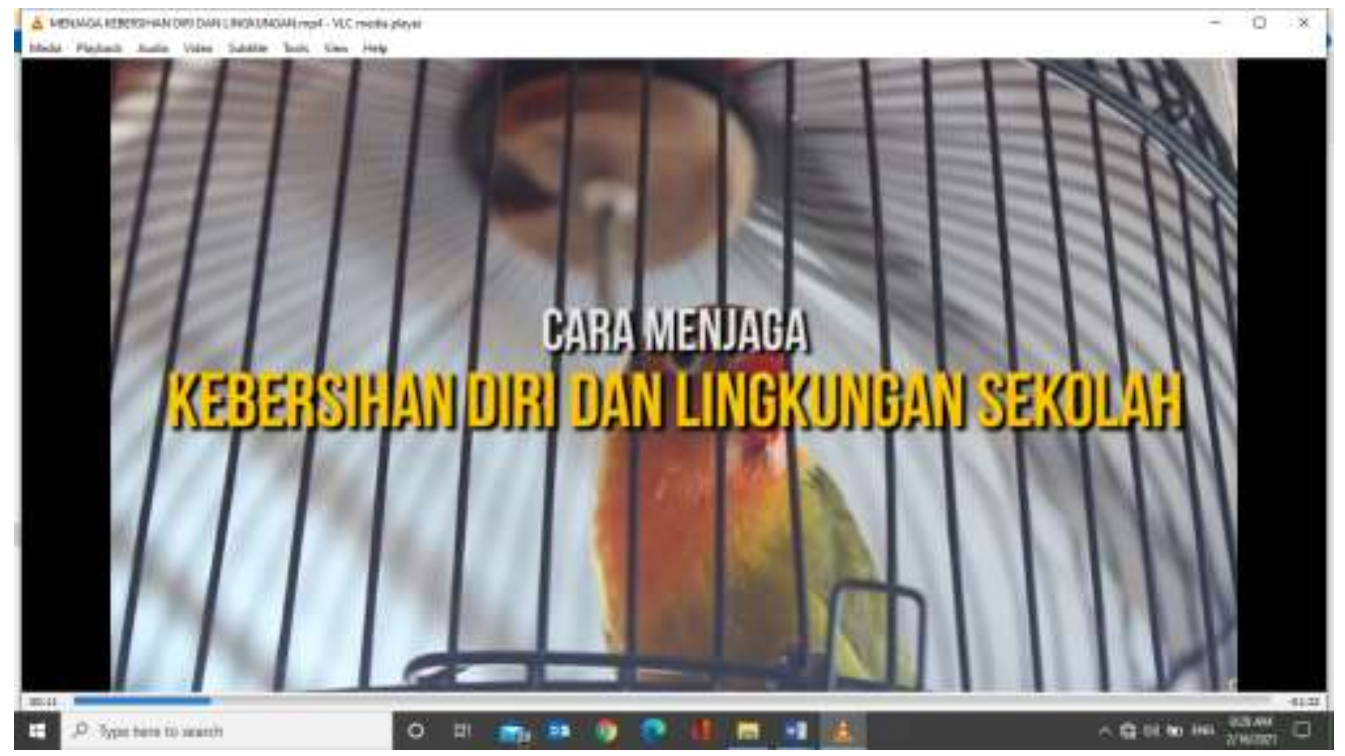

Gambar 2. Opening Title Video Edukasi

"Membangun Kesadaran Kebersihan Diri dan Lingkungan"

Tahap pascaproduksi merupakan tahapan untuk menggabungkan hasil produksi sesuai dengan skenario yang telah ditetapkan dalam tahap praproduksi. Tahap pascaproduksi mencakup kegiatan editing offline, editing mixing, dubbing, pemilihan musik, efek suara atau soundtrack, mastering, dan launching. Hasil akhir dari pembuatan video edukasi tersebut dapat dilihat pada Gambar 2 di atas.

Terkait poster edukasi, sama halnya dengan proses pembuatan video edukasi, poster edukasi ini dibuat melalui tahapan:

1. Menentukan tema poster.

2. Merumuskan pesan yang ingin disampaikan pada poster.

3. Menyusun kalimat yang singkat, jelas, dan mudah dipahami namun padat makna.

4. Memilih kata-kata dan gambar yang akan digunakan dalam poster yang mudah untuk diingat juga menarik.

5. Menuliskan kata-kata dan menyusun gambar dengan memperhatikan perpaduan warna dan tata letak sehingga poster tersebut menarik perhatian sekaligus mudah diingat (Graver \& Jura, 2012).

Tema yang dipilih untuk poster sama dengan tema yang telah ditetapkan dalam pembuatan video edukasi. Demikian juga pesan yang ingin disampaikan disamakan dengan pesan yang disampaikan dalam video. Hanya yang menjadi pertimbangan utama dalam 
pembuatan poster adalah faktor pemilihan huruf, besar kecilnya huruf sehingga tetap mudah dibaca, pemilihan gambar yang akan digunakan serta layout atau penyusunan elemen-elemen poster tersebut sehingga perpaduannya dapat menghasilkan poster yang menarik, mudah dipahami, dan diingat oleh setiap orang yang melihatnya. Diputuskan bahwa poster yang akan dibuat berjumlah 4 buah yang terdiri dari poster yang berisi pesan untuk membuang sampah pada tempatnya (gambar 3), ajakan untuk menjaga kelas tetap bersih (gambar 4), ajakan untuk menerapkan protokol kesehatan dengan selalu menggunakan masker saat keluar rumah (gambar 5), dan ajakan untuk selalu mencuci tangan dengan menggunakan sabun dan air mengalir untuk mencegah terkena paparan Covid-19 (gambar 6).

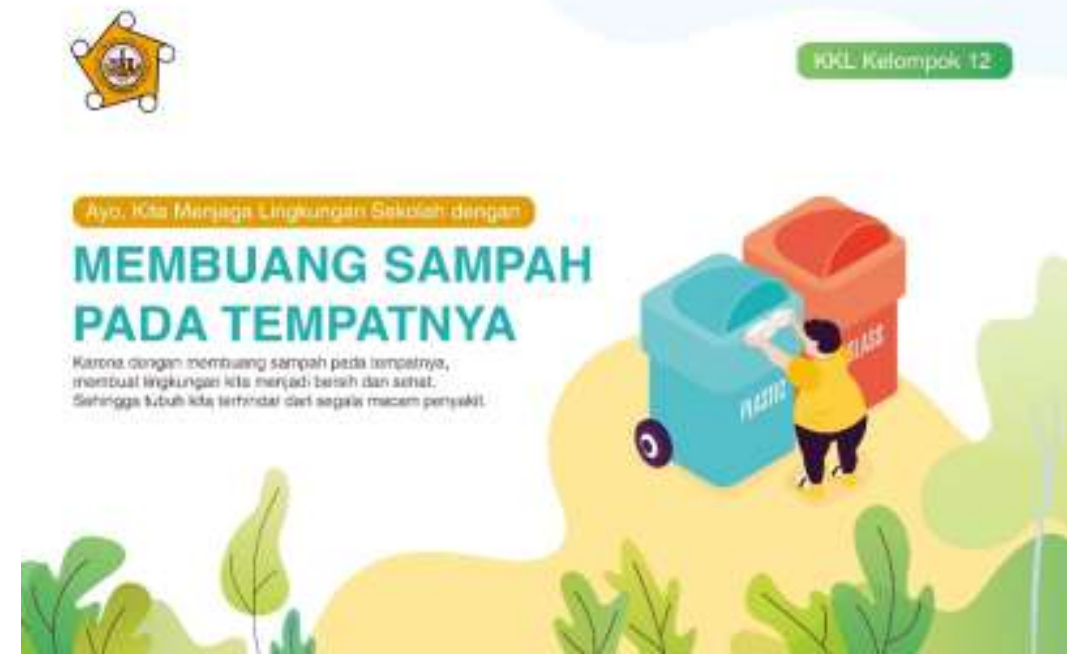

Gambar 3. Poster "Membuang Sampah Pada Tempatnya"

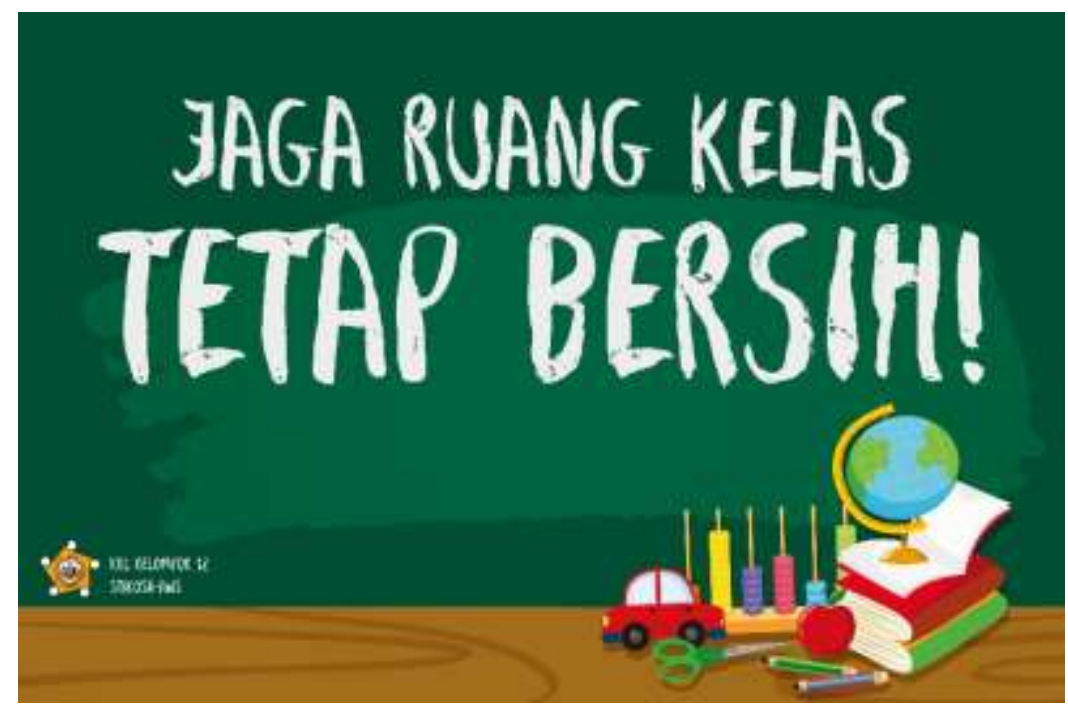

Gambar 4. Poster "Jaga Ruang Kelas Tetap Bersih" 


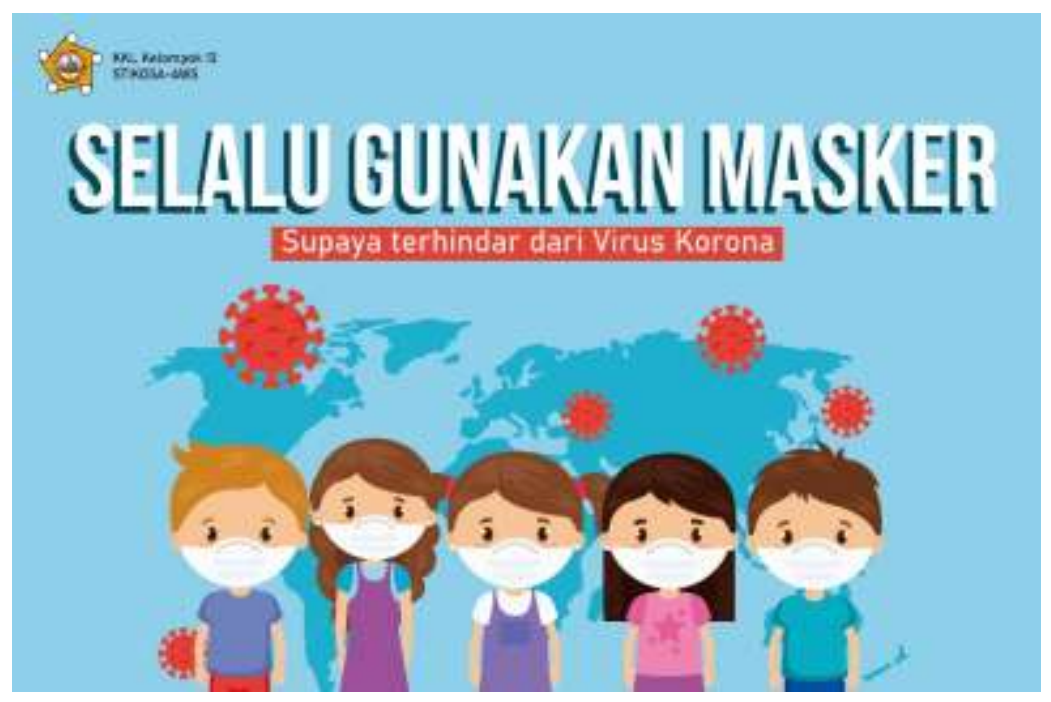

Gambar 5. Poster "Selalu Gunakan Masker"

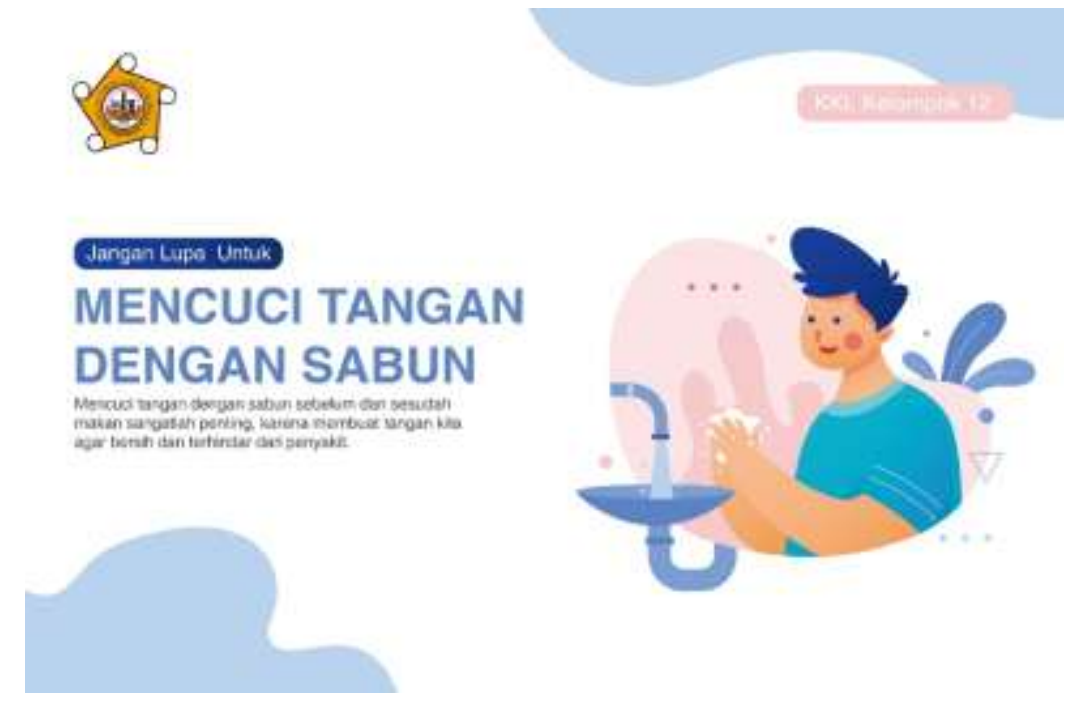

Gambar 6. Poster "Mencuci Tangan Dengan Sabun"

\subsection{Evaluasi dari Pihak Sekolah}

Akibat pandemi Covid-19 yang penyebarannya masih tinggi di Indonesia pada umumnya dan Surabaya pada khususnya, menyebabkan proses belajar mengajar di sekolah maupun perguruan tinggi dilakukan dengan menggunakan metode pembelajaran jarak jauh. Oleh karena itu, tim PkM juga tidak bisa memutarkan video ini di kelas-kelas pada Tk dan SD Tunas Benih Kasih Surabaya. Video dan poster edukasi yang bertemakan "Membangun Kesadaran Kebersihan Diri dan Lingkungan”, setelah melalui tahap pascaproduksi kemudian diserahkan kepada Kepala Sekolah, Ibu Debora Lelly Surdaryati, S.Pd., untuk selanjutnya dapat digunakan oleh pihak sekolah dalam mengedukasi siswa agar lebih peduli terhadap kebersihan diri dan lingkungan di sekitar mereka. 


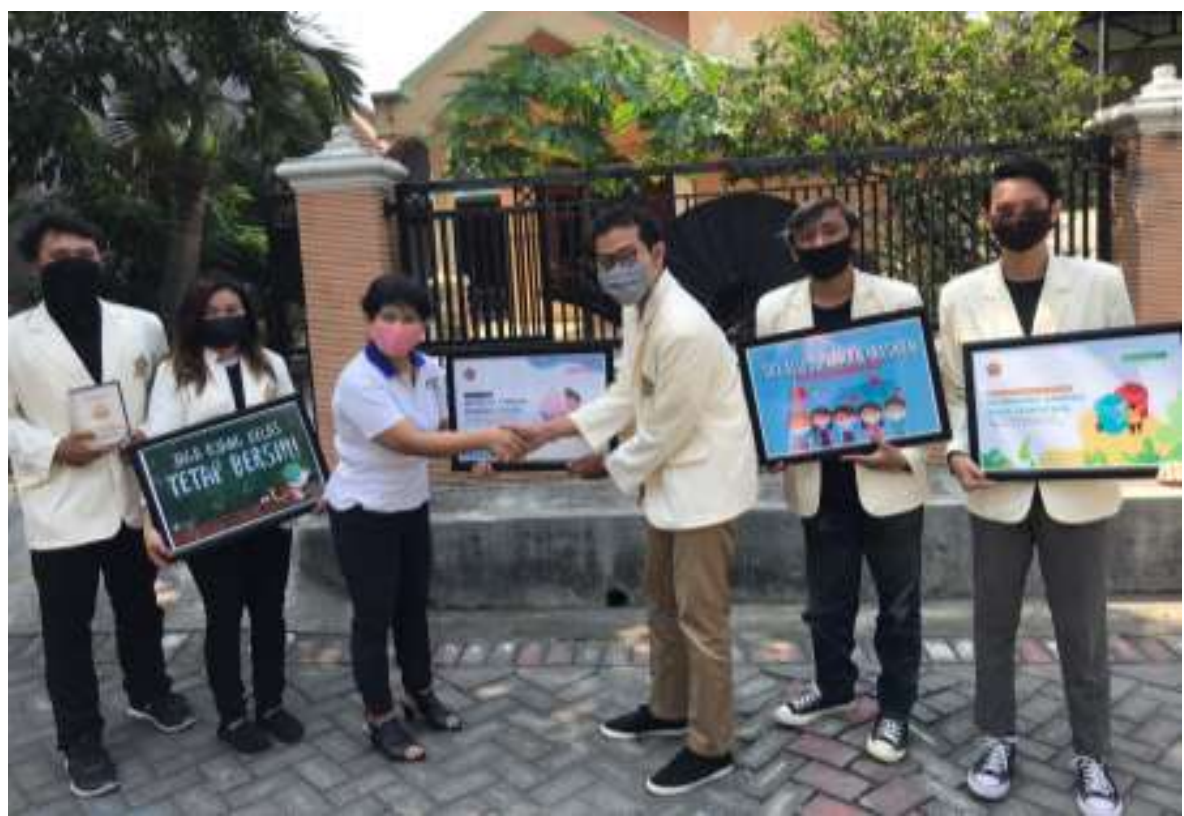

Gambar 7. Penyerahan Poster dan Video Edukasi kepada Pihak Sekolah TK dan SD Tunas Benih Kasih Surabaya

Harapan dari tim PkM adalah setelah siswa TK dan SD Tunas Benih Kasih menyaksikan tayangan video ini mereka dapat lebih tergerak untuk mau menjaga kebersihan diri dan lingkungan karena salah satu cara untuk mengajarkan anak-anak untuk mau menjaga kebersihan adalah dengan mengajak mereka untuk lebih mengenal lingkungan serta memberikan contoh-contoh nyata bagaimana cara menjaga kebersihan diri, cara untuk membuang sampah pada tempatnya atau cara untuk menjaga diri dari paparan Covid-19 dengan menerapkan protokol kesehatan. Video menjadi metode yang paling bisa mengena pada anak-anak usia 4-12 tahun karena dalam video bisa diberikan contoh-contoh yang dapat dilihat dan didengar oleh mereka. Untuk itu, ke depan, kegiatan PkM ini dapat dilanjutkan dengan melakukan penelitian menggunakan metode eksperimental untuk mengetahui dampak tayangan video dan poster edukasi tersebut terhadap kesadaran siswa TK dan SD Tunas Benih Kasih Surabaya dalam menjaga kebersihan diri dan lingkungan. Kebijakan pembelajaran jarak jauh yang saat ini diberlakukan di Indonesia, tidak memungkinkan tim PkM untuk menayangkan video edukasi ini dan menampilkan poster di depan para siswa sehingga efek dari tayangan video dan poster ini belum bisa diketahui.

Meskipun demikian, pihak sekolah setelah menyaksikan video edukasi tersebut menyatakan bahwa topik yang dipilih sangat menarik dan terkini (up to date), konten video mudah dipahami dan dipraktikkan, video dinilai sebagai media belajar yang sangat menarik yang dapat membangun motivasi murid untuk menjaga kebersihan diri dan lingkungan. Sementara evaluasi pihak sekolah terhadap poster adalah topik yang dipilih untuk disampaikan ke siswa cukup terkini (up to date) mulai dari ajakan untuk membuang sampah pada tempatnya, ajakan untuk menjaga kelas agar tetap bersih, ajakan untuk menerapkan protokol kesehatan dengan menggunakan masker ketika ke luar rumah, dan selalu mencuci tangan dengan sabun dan air mengalir. Pihak sekolah juga memuji bahwa gambar yang digunakan 
dalam poster sangat menarik sehingga diharapkan poster ini dapat menarik perhatian siswa untuk mau mempraktikkan pesan yang disampaikan dalam poster tersebut.

\section{PENUTUP}

Tidak perlu diragukan lagi bahwa kesadaran untuk menjaga kebersihan diri dan lingkungan sangat bermanfaat bagi semua makhluk hidup karena akan menciptakan kehidupan yang aman, bersih, dan sehat. Kebersihan diri dan lingkungan dapat menghindarkan kita dari berbagai penyakit yang disebabkan oleh bakteri dan virus yang menyebabkan pertumbuhan dan perkembangan ragam penyakit, terlebih di masa merebaknya pandemi Covid-19 seperti saat ini. Lingkungan dan diri sendiri akan menjadi lebih baik jika kita semua menyadari dan bertanggung jawab terhadap kebersihannya. Oleh karena itu, kesadaran akan kebersihan diri dan lingkungan harus ditanamkan sejak dini, baik melalui edukasi dalam proses belajar mengajar di sekolah maupun dalam keluarga. Diharapkan melalui video dan poster edukasi yang dibuat oleh tim PkM sebagai upaya untuk mengedukasi siswa TK dan SD Tunas Benih Kasih Surabaya, dapat membangun kesadaran siswa agar lebih peduli terhadap kebersihan diri dan lingkungan di sekitarnya. Selanjutnya, melalui poster dan video edukasi ini, pesan akan pentingnya kebersihan diri dan lingkungan serta manfaatnya bagi masyarakat, dapat tersebar semakin luas sehingga mimpi mewujudkan Indonesia yang bersih dan upaya membangun sumber daya manusianya yang sehat dapat terwujud. Untuk itu, marilah kita mulai selalu mengupayakan hidup bersih dan sehat dari diri kita sendiri dengan memberikan contoh kepada orang lain, terutama anak-anak, bagaimana cara menjaga kebersihan diri dan lingkungan.

\section{DAFTAR PUSTAKA}

Bili, S., Telly, M., \& Tanaem, N. F. D. (2019). Pengaruh pendidikan kesehatan dengan audio visual terhadap perilaku pencegahan penularan pada keluarga dengan tuberkulosis paru di wilayah kerja Puskesmas Sikumana. CHMK Health Journal, 3(2), 20-26.

Dinas Perumahan, Permukiman dan Pertahanan. (2020, 7 Januari). Kebersihan Lingkungan. Dikutip dari https://disperkimta.bulelengkab.go.id/artikel/kebersihan-lingkungan87\#: :text=Manfaat\%20menjaga\%20kebersihan\%20lingkungan\%20antara\%20lain\%3

A\&text=Terhindar\%20dari\%20penyakit\%20yang\%20disebabkan,dan\%20aman\%20unt uk\%20di\%20minum.

Graver, A., \& Jura, Ben. (2012). Best practices for graphic designer: Grids and page layouts. Beverly, MA: Rockport Publisher.

Harsismanto, Oktavidiati, E., \& Astuti, D. (2019). Pengaruh pendidikan kesehatan media video dan poster terhadap pengetahuan dan sikap anak dalam pencegahan penyakit diare. Jurnal Kesmas Asclepius, 1(1), 75-85. doi:10.31539/jka.v1i1.747

Jawa Pos. (2020, 31 Oktober). Korona Musuh Bersama. Jawa Pos, Rubrik Ubah Laku, pp. 21.

Kanflic, C. N. (2015). Storytelling with data: A data visualization guide for business professionals. Hoboken, NJ: John Wiley \& Sons, Inc.

Lankow, J., Crooks, R., \& Ritchie, J. (2012). Infographics the power of visual storytelling. Hoboken, NJ: John Wiley \& Sons, Inc.

Rahmatina, L. A., dan Erawati, M. (2020). Evaluasi program edukasi dengan video dan poster terhadap perilaku masyarakat dalam menghadapi Covid-19 (preliminary study). 
Journal of Holistic Nursing and Health Science, 3(1), 9-16. Dikutip dari https://ejournal2.undip.ac.id/index.php/hnhs

Satgas Penanganan Covid-19. (2021, 13 Februari). Peta Sebaran Covid-19. Dikutip dari https://covid19.go.id/peta-sebaran-covid19

Walter, E., \& Gioglio, J. (2014). The power of visual storytelling: How to use visuals, video, and social media to market your brand. New York: McGraw-Hill Education.

Zettl, H. (2003). Television, Production Handbook. San Fransisco State University: Thomson, Wadsworth. 